\title{
Gorzkie żale przybywajcie... \\ red. Stanisław Urbański, Janusz Śmigiera, Wydawnictwo UKSW, Warszawa 2008, s. 291
}

We współczesnym duszpasterstwie pojawia się niejednokrotnie pytanie, które dotyczy zaangażowania w życie parafialne wiernych. Przemiany soborowe, a może bardziej sposób ich interpretacji, zostały odczytane jako konieczność zachowania jedynie tego co niezbędne, aby wśród „środków ubogich” szukać spotkania z Bogiem. Efektem wielu z podejmowanych „reform” stał się zanik nieszporów w prawie wszystkich parafiach, a "przepracowani” duchowni niejednokrotnie pomogli w zapomnieniu o nabożeństwach okresowych.

Oczywiście tego rodzaju spojrzenie może zostać uznane za cokolwiek niesprawiedliwe i upraszczające. Nikt jednak nie zaprzeczy, że tzw. ludowe duszpasterstwo nie znalazło innego, lepszego zamiennika. Intuicja Prymasa Tysiąclecia prowadziła tysiące wiernych do miejsc świętych, a sanktuaria stawały się na nowo żywymi centrami spotkania człowieka z Bogiem w sakramencie pokuty i Eucharystii. Masowe duszpasterstwo nie zakłada zaniku spojrzenia personalistycznego, lecz pomaga w odkrywaniu osoby we wspólnocie, która nie utrudnia rozwoju życia duchowego, ale pomaga w jego wzmacnianiu.

Kościół w Polsce może cieszyć się znakami żywej wiary w miejscach świętych, które stają się celem licznych pielgrzymek. Sanktuaria Maryjne, czy liczne Kalwarie są świadectwem wiary oraz kultury społeczności, która kształtowała się w świetle Ewangelii. Każda społeczność ukazuje charakterystyczne rysy swej pobożności oraz demonstruje cechy, które weryfikują się w codzienności. Fenomenem polskiej pobożności są nabożeństwa pasyjne, a ich szczególnym wyrazem wydaje się nabożeństwo „Gorzkich żalów”. Można uznać je za szczególny rys pobożności polskiej, bowiem powstało w naszym kraju, a wyśpiewane po raz pierwszy w 1707 roku w kościele Świętego Krzyża w Warszawie niesie do dziś szanse spotkania człowieka z Bogiem w rozpamiętywaniu zbawczych wydarzeń Męki Pańskiej.

Miejsce i czas splatają się w jedno i dają przestrzeń w coraz lepszym odczytywaniu dziedzictwa wieków. Kościół Świętego Krzyża w Warszawie przy Krakowskim Przedmieściu już od ponad 300 lat rozbrzmiewa śpiewami przybliżającymi pasyjne wydarzenia. Obecna Bazylika Mniejsza św. Krzyża w ostatnich dziesiątkach lat stała się także amboną, z której rozchodziło się słowo wolności na falach radiowych, budując podstawy pod niepodległość Rzeczpospolitej. Od lat także nabożeństwa pasyjne gromadzą wiernych w świątyni i przy odbiornikach radiowych, aby wyśpiewywać modlitwy ułożone na wzór Liturgii Godzin, 
która staje się liturgią nie tylko z obowiązku, lecz otwartości i pragnienia serc. Nabożeństwo pasyjne jest także okazją do wysłuchania kazań pasyjnych, które zwykle zostają także uwiecznione drukiem.

Jubileusz 300-lecia wykonania „Gorzkich żalów” stał się okazją do zorganizowania ogólnopolskiego sympozjum jubileuszowego. Wspólny trud podjęły: Polska Prowincja Zgromadzenia Misjonarzy, parafia św. Krzyża w Warszawie, Instytut Teologiczny Księży Misjonarzy w Krakowie, Instytut Filologii Polskiej UKSW oraz Sekcja Teologii Duchowości UKSW. Wspólne przedsięwzięcie zaowocowało pracami, które ukazały się w publikacji Gorzkie żale przybywajcie... Studia i szkice w 300-lecie powstania Gorzkich żalów. Książkę wydało Wydawnictwo UKSW w Warszawie, a jej redaktorami są ks. prof. dr hab. Stanisław Urbański oraz ks. lic. Janusz Śmigiera CM. Publikacja sygnowana nazwiskiem ks. prof. Urbańskiego wskazuje na kierunek podejmowanych rozważań, dlatego oznaczona jest także jako 73. pozycja w serii Mistyki Polskiej.

Już sama okładka wskazuje na tematykę podjętą w książce, niestety, czytelnik nie dowie się z żadnego miejsca omawianej publikacji skąd pochodzi wymowna reprodukcja. Na stronach 5 i 6 umieszczono spis treści, który pozwala wywnioskować w pewnym stopniu kim są autorzy poszczególnych przedłożeń. Poszczególne tytuły artykułów wskazują na wielkie bogactwo zawartych w nich treści, które dotykają pobożności ludowej, duchowości maryjnej, mistyki, aż po stronę muzyczną omawianych treści. Szkoda, że nie umieszczono pod poszczególnymi artykułami tytułów rozdziałów, co umożliwiłoby bardziej efektywne wejrzenie w prezentowane treści.

Uwarunkowania historyczne oraz dzieła podejmowane przez zgromadzenia zakonne wyciskały piętno na kształtującym się obliczu polskiego katolicyzmu. Przybyli w 1651 roku dzięki staraniom królowej Ludwiki Marii Gonzagi misjonarze św. Wincentego à Paulo nie tylko zajęli się dziełami dobroczynności, ale podjęli posługę, która przez długie dziesiątki lat wydawała swoje owoce. Oni właśnie zajęli się kształtowaniem i przygotowywaniem kandydatów do kapłaństwa. Prowadząc powierzane im przez biskupów seminaria duchowne i głosząc misje ludowe, dostrzegali potrzeby duchowe, wobec których nie pozostawali głusi. Stąd warto zwrócić uwagę na tekst ks. Stanisława Rosponda CM „Gorzkie żale na tle historii Zgromadzenia Księży Misjonarzy w Polsce i kościoła św. Krzyża w Warszawie" (s. 15-26). Ważnym aspektem, który rysuje się na tle przywoływanych faktów jest konstatacja, która pokazuje nabożeństwo „Gorzkich żalów” jako dowartościowanie języka polskiego.

Aspekt znaczenia i wagi nabożeństwa z 1707 roku ujawnia się w spojrzeniu na historię literatury polskiej, która nieprzerwanie była utwierdzana intelektualnym i duchowym wysiłkiem ludzi Kościoła. Bez wątpienia warto podkreślać to także dzisiaj, bowiem pokolenie średnie i starsze, a także kształtowana przez nich młodzież może z duchem czasów minionego systemu totalitarnego zapominać, 
że przed nazwiskiem Ignacy Krasicki czy Jan Paweł Woronicz jest określenie biskup albo arcybiskup. Bernadetta Kuczera-Chachulska w tekście „Gorzkie żale jako przykład liryki medytacyjnej” (s. 139-150), Magdalena Saganiak w artykule „Doświadczenie religijne i doświadczenie estetyczne w nabożeństwie Gorzkich żalów” (s. 151-186), czy Teresa Winek w przedłożeniu „Echa Gorzkich żalów w literaturze polskiej XIX wieku" (s. 205-220) przybliżyły, jaki wpływ wywarło nabożeństwo z kościoła św. Krzyża na literaturę kształtującą myśli i postawy.

"Gorzkie żale" jako wyraz pobożności ludowej i pełnej pokory postawy spoglądania na dzieło odkupienia człowieka nigdy nie pozostają tanim sentymentalizmem. Szczere i głębokie spojrzenie na cierpienie Matki i Syna wiedzie ku zjednoczeniu z Bogiem. Teksty ks. Stanisława Urbańskiego „Mistyka pasyjna Gorzkich żalów” (s. 27-42) oraz „Mistyka pasyjna polskich mistyczek” (s. 115-138) przybliżają czytelnikowi wagę pasyjnego spojrzenia na drodze rozwoju duchowego. Przywołana bodaj najsłynniejsza polska mistyczka św. s. Faustyna, czy s. Leonia Nastał i inne, ukazują zjednoczenie z Mistrzem w chwilach największej próby miłości.

Można stwierdzić, że nie wszyscy doświadczą wejścia na drogę życia mistycznego, nie każdy także zadowoli się stwierdzeniem, że "Gorzkie żale” są wyrazem pobożności ludowej. Ksiądz Jan Rusiecki SDB w artykule "Gorzkie żale jako wyraz pobożności ludowej w świetle dokumentów Kościoła” (s. 61-88) przywołał m.in. „Dyrektorium o pobożności ludowej i liturgii. Zasady i wskazania” z 17 grudnia 2001 roku oraz wiele innych dokumentów papieskich, które wbrew mylnym stereotypom dowartościowują nabożeństwa jako przygotowanie i wprowadzenie w spotkanie z Bogiem. Niezwykle istotnym elementem rozważań o „Gorzkich żalach” jest aspekt paschalny i eucharystyczny. Przy odrobinie dobrej woli i otwartości na tradycję wieków nikt nie stwierdzi, że wystawienie Najświętszego Sakramentu w czasie „Gorzkich żalów” czy nabożeństwa różańcowego zaciera wymiar eucharystyczny liturgii Kościoła.

Wśród wielości aspektów, które wiążą się z historią i praktyką pasyjnego nabożeństwa z kościoła św. Krzyża warto zwrócić uwagę jeszcze na choćby jeden aspekt. Jest to wymiar niezwykle dynamiczny, bowiem te same wydarzenia pasyjne przeżywane $\mathrm{w}$ tych samych wyśpiewanych strofach i ewangelicznych obrazach, mają być zgłębiane i interpretowane żywym słowem kaznodziei. Ksiądz Władysław Bomba CM mówi o „Fenomenie kazań pasyjnych” (s. 89-96), a o. Andrzej Baran OFMCap „Kazania pasyjne kapucynów w XVIII i XIX wieku” (s. 97-114). Obaj dotknęli niezwykle istotnej z punktu widzenia duszpasterskiego sfery. Kaznodzieja jest tym, który towarzyszy człowiekowi w jego drodze z Chrystusem, pomaga dyskretnie znaleźć się blisko Pana. Kazania pasyjne przez umiejscowienie w konkretnym czasie i konkretnych okolicznościach mają do spełnienia niezwykle ważną rolę. 
Wszystkie dotknięte treści, a także pozostałe teksty umieszczone w publikacji Gorzkie żale przybywajcie... nie tylko wypełniają jubileuszowe zapotrzebowanie na pewną rekapitulację i chwilę zadumy, ale są także próbą odkrycia bogactwa niedocenionego, a przecież tak bliskiego. Wymiar kulturowy i kulturotwórczy, a nade wszystko wymiar duchowego rozwoju i umocnienia, pozwala na patrzenie z nadzieją na dalsze badania i wnioski. Jednocześnie warto zobaczyć ciągle żywą potrzebę głębszego wysiłku duszpasterskiego, który zaowocuje trwałymi postawami chrześcijańskimi, wchodzącymi w treści, które w ewangelicznej dynamice dotykają każdego i każą dokonywać wyborów i znajdować codzienne odpowiedzi.

Ks. Jerzy Swędrowski 